\title{
Factors of Medical Risks Related to the Production and the Sale of the Groundnut Paste in the Markets of the Town of Abidjan (Côte d'Ivoire)
}

\author{
Zamble A. BOLI ${ }^{1 *}$, Celah A. KAKOU ${ }^{1}$, Djegba Marie TOKA ${ }^{1}$, Rose KOFFI-NEVRY ${ }^{1}$ \\ ${ }^{1}$ Laboratory of Biotechnology and Food Microbiology, Department of Food Science and Technology (UFR-STA), University Nangui \\ Abrogoua, 02 BP 801, Abidjan 02, Côte d'Ivoire,
}

Corresponding Author: *Zamblé A. BOLI, bzia2011@yahoo.fr

Date of Receipt: 18.03.2016, Date of Acceptance: 27.04.2016, Date of Publication: 29.05.2016

\begin{abstract}
This study was conducted to evaluate the risks related to the consumption of groundnut paste produced and sale in the markets of Abidjan (Côte d'Ivoire), through an investigation. The mills being used for grinding of groundnut seeds have in a general way a general-purpose use (76, 7 to 91, $3 \%$ ). The mills (78, 6 to 97, $2 \%$ ) are used daily. However, 41, 7 to 82, $2 \%$ of the cases are not cleaned after the various uses. The same ones store groundnut pastes are sold during 1 to 3 months. However, the majority of the saleswomen (82, $19 \%$ ) does not protect them during marketing. Generally, the millers and the saleswomen of groundnut paste do not give any detailed attention to the prevention of the medical risks in the units of grinding and during the sale.
\end{abstract}

Keywords: Production, groundnut paste, mills, markets

\section{Introduction}

The groundnut (Arachis Hypogaea) is an oleaginous plant belonging to the Arachis kind, of the family of Fabaceae which includes the majority of leguminous seeds and having a high importance economic and nutritive [5]-[19]. It is a tropical plant originating in South America which was introduced in Africa, Asia and Europe [12]-[8]. The groundnut is the fifth culture among the most significant oilseeds in the world [22], the second edible source of oil [16], the third significant source of plant proteins and the twelfth vegetable production in the world [7]. It is cultivated on 25, 44 million hectares in the world for a production estimated at 45, 22 million tons and an average productivity of 1, 8 ton per hectare in 2013 [6]. After Asia, first producing continent, with China and India respectively 13 and 9 million tons of production, the African continent occupies the second place with 10 million tons. The production of the Ivory Coast records a constant progression of 81 thousand tons in 2008, with 93, 5 thousand tons in 2012 [4].

In Africa, the sale of groundnut as well remains a generating activity of incomes for the populations in rural medium into urban [3].

The groundnut is mainly transformed into oil, paste, flour and various derivatives which enter the composition of foodstuffs. It is a good source of lipids, proteins, minerals, of carbohydrates, fibres, vitamin $E$ and energy contributions [11]. Medical studies showed that the groundnut consumption reduces the cardiovascular risks of diseases [9]. The groundnut paste one of the products derived from groundnut appreciated and is the most consumed in many hearths African [17]-[18].

In sub-Saharan Africa and particularly in Côte.d'Ivoire, the groundnut paste is primarily produced in a way artisanal and marketed directly on the markets without any control of the authorities. The production of the groundnut pastes is done primarily by means of the mills established in the majority of the markets of the town of Abidjan. However, the medical risks associated the conditions of the production and its sale of groundnut are numerous.

The present study proposed to index the medical risks dependent on the production and of its sale of the groundnut paste through a collection of information near the millers and saleswomen of groundnut paste in the markets of Abidjan (Côte d'Ivoire).

\section{Materials and Methods}

\section{Zone of Study}

The town of Abidjan gathers 10 communes in particular Abobo, Adjamé, Attécoubé, Cocody, Koumassi, Marcory, Plateau, Port-Bouët, Treichville and Yopougon (Figure 1). It's choice is justified by its demographic and economic importance. It is the mégalopole most populated country with 5878609 inhabitants of inhabitants in 2009 according to the Institute Main road of the Statistics. It's economic activity results in the presence of a multitude of markets and commercial stores which are the places of provisioning and unloading of the food products coming from the interior of the country.

\section{Preparation of investigation}

An pre-investigation was carried out to count into the ground, the places of production and sale of the groundnut pastes in the markets of the town of Abidjan. It lasted one month and made it possible to observe and design a survey questionnaire. 


\section{International Journal of Science and Research (IJSR) \\ ISSN (Online): 2319-7064}

Index Copernicus Value (2013): 6.14 | Impact Factor (2015): 6.391

\section{Inquire preliminary}

The investigation proceeded in 9 communes of the town of Abidjan to knowing : Abobo, Adjamé, Attécoubé, Cocody, Koumassi, Marcory, Port-Bouët, Treichville and Yopougon. The population of study was made up on the one hand, millers and on the other hand, saleswomen of groundnut paste exerting in the markets of each commune. The investigation of ground realized by means of cards of questionnaire made it possible to collect information in the millers on the versatility, the use, cleaning after use and the frequency of use of the mills. The choice of the markets is conditioned on the one hand, by the number of mills (at least 5) preexistent and on the other hand, by the quantity of the groundnut paste produced within the units of grinding (at least $100 \mathrm{~kg} / \mathrm{semaine}$ ). This study concerned 270 questioned millers in a random way at a rate of 30 millers per commune. As for the saleswomen of groundnut paste, their characteristics (the age, the level of study and the commercial experiment), the source of their groundnut paste sold, the protection of their groundnut paste during the sale as well as the duration of sale of the same stock of groundnut paste were given. This part concerned 450 saleswomen of questioned groundnut paste (50 per commune). On the whole, the investigation related to 720 people at a rate of 270 millers and 450 saleswomen of groundnut paste over one 5 months period within the principal markets of nine communes of the town of Abidjan (Figure 1).

\section{Statistical Analysis}

The various results obtained were treated with the software Statistica version 7.1. In the event of significant difference between the studied parameters, a variance analysis (ANOVA) was carried out and the classification of average was made according to the test of Duncan to the threshold of significance $\alpha$ of $5 \%$. The differences are regarded as significant for values of $\mathrm{P}<0,05$.

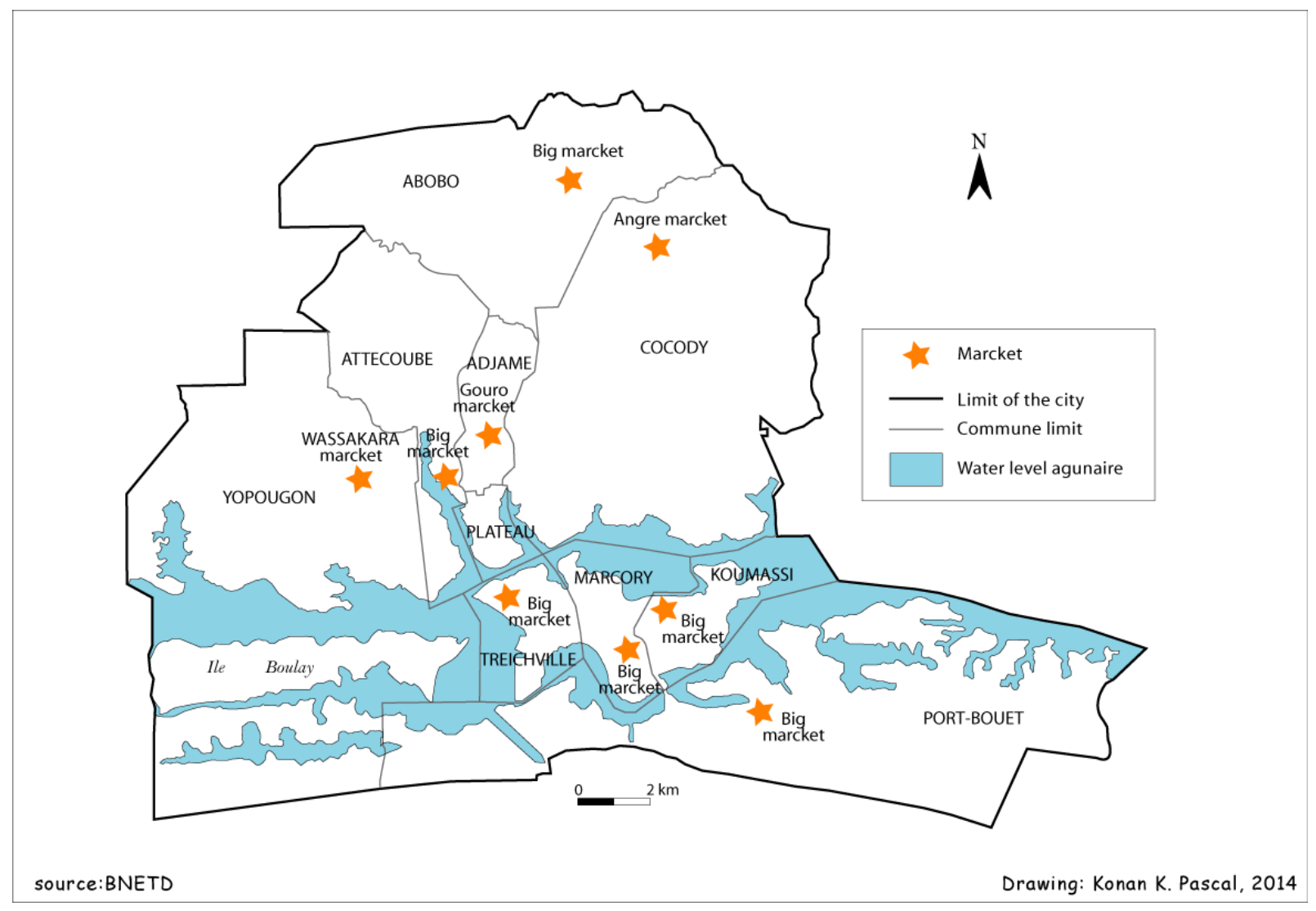

Figure 1 : Chart of the town of Abidjan presenting the places of production of the groundnut paste in certain markets of the town of Abidjan

\section{Results and Discussion}

\section{Results}

The distribution of the various uses of the mills in the markets is presented in figure $\mathbf{2}$. In a general way, the mills have a general-purpose use $(76,7 \%$ to $91,3 \%)$ whatever the commune. The mills are used daily $(78,6$ to $97,2 \%)$ for the treatment of the various food groups (Figure 3).
The table 1 indicates that the sale of the groundnut paste in the markets is exclusively carried out by the women. The majority of the saleswomen has an age ranging between 20 and 45 years. However, few saleswomen have an age higher than 60 years $(5,84 \%)$. The saleswomen of groundnut paste in the markets are to $73,4 \%$ illiterate. However, 15, $43 \%$ have the primary education level, 10 , $75 \%$ the secondary level and $0,42 \%$ the higher level. The majority of the saleswomen $(44,7 \%)$ had experience from 2 to 5 years in the sale of the groundnut paste, followed those which have between 6 and 11 years of experiment 


\section{International Journal of Science and Research (IJSR) \\ ISSN (Online): 2319-7064 \\ Index Copernicus Value (2013): 6.14 | Impact Factor (2015): 6.391}

(26, $21 \%$ ) against only 2, $68 \%$ whose commercial experiment was included understood enters 24 to 29 years. The table 2 shows that $43,81 \%$ of the saleswomen market the same stock of groundnut paste to the detail until exhaustion over one minimal duration of 1 month tells 27 , $48 \%$ of the saleswomen over one period from 1 to 2 months and 14, $89 \%$ over one period from 2 to 3 months. It arises from table 3 that the majority of the saleswomen, that is to say $82,19 \%$ do not protect the paste from groundnut during the sale counters only $17,81 \%$. It is the made case of the saleswomen of the communes of Abobo (92, $7 \%$ ), of Attécoubé (88, $5 \%$ ), Yopougon (85, $3 \%$ ) and Adjamé $(85,2 \%)$ which do not cover in their great majority the groundnut paste during the sale.

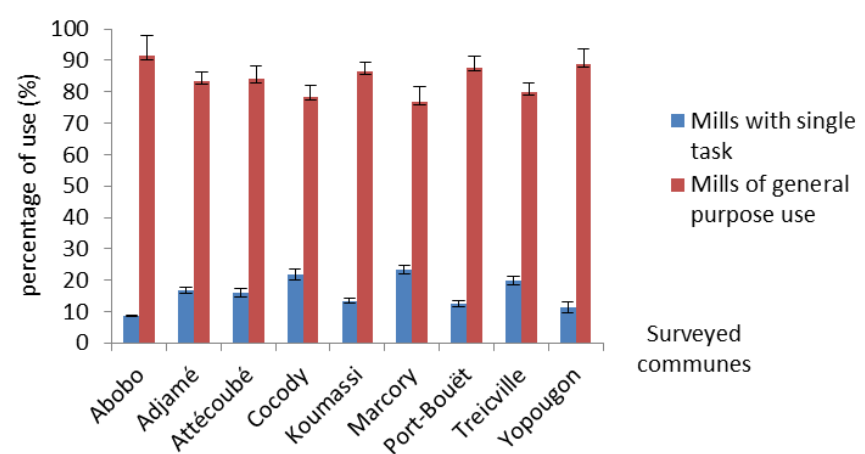

Figure 2 : Distribution of the various uses of the mills according to communes

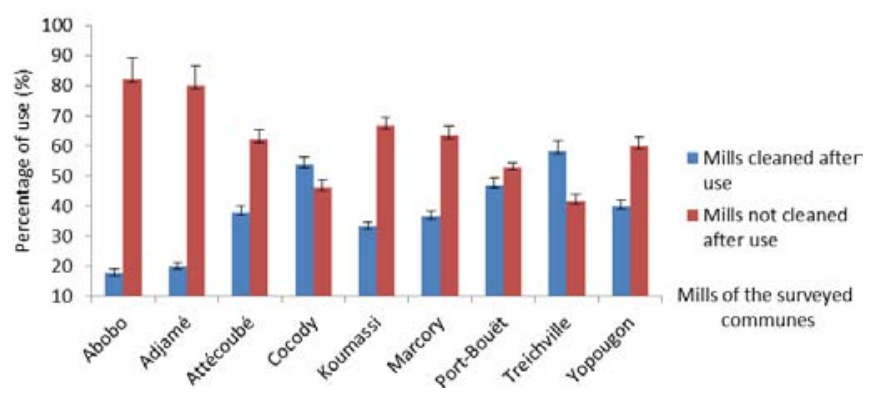

Figure 3 : Cleaning of the mills after use according to communes

Table 1: Distribution (\%) of the characteristics of the saleswomen of groundnut paste in the markets of Abidjan

\begin{tabular}{|c|c|c|c|c|c|c|c|c|c|c|}
\hline \multirow[b]{2}{*}{$\begin{array}{c}\text { Characteristics } \\
\text { of the } \\
\text { saleswomen }\end{array}$} & \multicolumn{10}{|c|}{ Communes investigated Averages } \\
\hline & Abobo & Adjamé & Attécoubé & Cocody & Koumassi & Marcory & Port-Bouët & Treichville & Yopougon & \\
\hline \multicolumn{11}{|l|}{ Age (years) } \\
\hline $20-30$ & $46,7^{\mathrm{a}}$ & $43,3^{\mathrm{a}}$ & $43,67^{\mathrm{a}}$ & $43,6^{\mathbf{a}}$ & $33,3^{\mathbf{b}}$ & $46,7^{\mathrm{a}}$ & $48,6^{\mathbf{a}}$ & $56,00^{\mathrm{a}}$ & $44,1^{\mathrm{a}}$ & $\begin{array}{c}45,10 \pm 8, \\
11\end{array}$ \\
\hline $30-45$ & $43,3^{\mathrm{a}}$ & $36,7^{\mathrm{a}}$ & $37^{\mathrm{a}}$ & $36,7^{\mathbf{a}}$ & $40^{\mathrm{a}}$ & $36,7^{\mathrm{a}}$ & $35,4^{\mathrm{a}}$ & $30^{\mathbf{a}}$ & $43,3^{\mathrm{a}}$ & $\begin{array}{c}37,68 \pm 11, \\
10\end{array}$ \\
\hline $45-60$ & $6,4^{\mathbf{b}}$ & $16,7^{\mathrm{a}}$ & $15^{\mathrm{a}}$ & $13^{\mathrm{a}}$ & $20^{\mathrm{a}}$ & $10^{\mathbf{b}}$ & $8^{\mathbf{b}}$ & $4^{b}$ & $9,3^{\mathbf{b}}$ & $\begin{array}{c}11,38 \pm 6 \\
92\end{array}$ \\
\hline$>60$ & $3,6^{\mathbf{b}}$ & $3,3^{\mathbf{b}}$ & $4,33^{b}$ & $6,7^{\text {ab }}$ & $6,7^{\mathbf{a b}}$ & $6,6^{\mathbf{a b}}$ & $8^{\mathbf{a}}$ & $10^{\mathbf{a}}$ & $3,3^{\mathbf{b}}$ & $5,84 \pm 2,37$ \\
\hline \multicolumn{11}{|l|}{ Kind } \\
\hline Male & - & - & - & - & - & - & - & - & - & - \\
\hline Female & $100^{\mathrm{a}}$ & $100^{\mathbf{a}}$ & $100^{\mathrm{a}}$ & $100^{\mathrm{a}}$ & $100^{\mathbf{a}}$ & $100^{\mathbf{a}}$ & $100^{\mathbf{a}}$ & $100^{\mathbf{a}}$ & $100^{\mathrm{a}}$ & $100 \pm 0,00$ \\
\hline \multicolumn{11}{|l|}{ Level of study } \\
\hline No & $73,3^{\mathrm{a}}$ & $80^{\mathbf{a}}$ & $84^{\mathrm{a}}$ & $70^{\mathrm{a}}$ & $83,3^{\mathbf{a}}$ & $80^{\mathbf{a}}$ & $43,3^{\mathbf{b}}$ & $33,7^{\mathbf{b}}$ & $83,4^{\mathrm{a}}$ & $\begin{array}{c}73,4 \pm 20 \\
16\end{array}$ \\
\hline Primary & $20^{\mathrm{a}}$ & $20^{\mathrm{a}}$ & $13,5^{b}$ & $20^{\mathrm{a}}$ & $13,3^{\mathbf{b}}$ & $16,7^{\mathrm{a}}$ & $22^{\mathrm{a}}$ & $21^{\mathrm{a}}$ & $13,3^{\mathbf{b}}$ & $\begin{array}{c}15,43 \pm 3 \\
33\end{array}$ \\
\hline Secondary & $6,7^{\mathbf{b}}$ & $0^{\mathbf{c}}$ & $2,5^{\mathbf{b}}$ & $10^{\mathbf{b}}$ & $3,4^{\mathbf{b}}$ & $3,3^{\mathbf{b}}$ & $33,3^{\mathbf{a}}$ & $43,3^{a}$ & $3,3^{\mathbf{b}}$ & $\begin{array}{c}10,75 \pm 8, \\
16\end{array}$ \\
\hline Higher & $0^{\mathbf{b}}$ & $0^{\mathbf{b}}$ & $0^{\mathbf{b}}$ & $0^{\mathbf{b}}$ & $0^{\mathbf{b}}$ & $0^{\mathbf{b}}$ & $1,4^{\mathbf{a}}$ & $2^{a}$ & $0^{\mathbf{b}}$ & $0,42 \pm 2,49$ \\
\hline \multicolumn{11}{|l|}{$\begin{array}{c}\text { Commercial } \\
\text { experiment } \\
\text { (years) }\end{array}$} \\
\hline $2-5$ & $30^{\mathbf{b}}$ & $30,4^{b}$ & $45^{\mathbf{b}}$ & $46,7^{\mathbf{b}}$ & $46,7^{\mathbf{b}}$ & $42,9^{\mathbf{b}}$ & $78,6^{\mathrm{a}}$ & $40^{\mathbf{b}}$ & $43,3^{\mathbf{b}}$ & $\begin{array}{c}44,7 \pm 16 \\
26\end{array}$ \\
\hline $6-11$ & $26,7^{\mathbf{b}}$ & $43,3^{\mathbf{a}}$ & $26,5^{\mathbf{b}}$ & $30^{\mathbf{b}}$ & $26,7^{\mathbf{b}}$ & $28,6^{\mathrm{b}}$ & $10,7^{\mathbf{c}}$ & $27^{\mathbf{b}}$ & $16,7^{\mathbf{c}}$ & $\begin{array}{c}26,21 \pm 9 \\
59\end{array}$ \\
\hline $12-17$ & $23,3^{\mathrm{a}}$ & $13,3^{\mathbf{a b}}$ & $15,3^{\mathrm{a}}$ & $16,7^{\mathbf{a}}$ & $20^{\mathrm{a}}$ & $17,9^{\mathbf{a}}$ & $7,1^{\mathbf{b}}$ & $20,8^{\mathbf{a}}$ & $16,7^{\mathrm{a}}$ & $\begin{array}{c}16,97 \pm 5 \\
01\end{array}$ \\
\hline $18-23$ & $16,7^{\mathbf{a}}$ & $10^{\mathbf{b}}$ & $9,5^{\mathbf{b}}$ & $3,3^{\mathbf{c}}$ & $6,6^{\mathbf{b c}}$ & $7,1^{\mathbf{b c}}$ & $3,6^{\mathbf{c}}$ & $8,2^{\mathbf{b c}}$ & $20^{\mathrm{a}}$ & $9,44 \pm 5,99$ \\
\hline $24-29$ & $3,3^{\mathrm{a}}$ & $3^{a}$ & $3,7^{\mathbf{a}}$ & $3,3^{a}$ & $0^{\mathbf{b}}$ & $3,5^{\mathrm{a}}$ & $0^{\mathbf{b}}$ & $4^{a}$ & $3,3^{\mathbf{a}}$ & $2,68 \pm 3,09$ \\
\hline
\end{tabular}

On line, the affected values of the same letter are not significantly different with the threshold from $5 \%$ according to Duncan's test 


\section{International Journal of Science and Research (IJSR) ISSN (Online): 2319-7064}

Index Copernicus Value (2013): 6.14 | Impact Factor (2015): 6.391

Table 2: Percentage of the saleswomen of the same stock of groundnut paste in the markets

\begin{tabular}{|c|c|c|c|c|c|}
\hline \multirow{2}{*}{$\begin{array}{l}\text { Communes } \\
\text { investigated }\end{array}$} & \multicolumn{5}{|c|}{ Percentage of the saleswomen of groundnut paste (\%) } \\
\hline & $\leq 1$ & 2 & 3 & 1 à 2 & 2 à 3 \\
\hline Abobo & $36,7 \pm 1,66^{d}$ & $16,7 \pm 8,89^{\mathrm{e}}$ & $10 \pm 1,00^{\mathbf{c}}$ & $16,3 \pm 1,04^{\mathbf{b}}$ & $20 \pm 1,00^{\text {cd }}$ \\
\hline Adjamé & $23,3 \pm 0,70^{b}$ & $13,4 \pm 1,40^{d}$ & $2,7 \pm 0,36^{b}$ & $27,3 \pm 0,61^{\mathrm{d}}$ & $33,2 \pm 1,97^{\mathrm{e}}$ \\
\hline Attécoubé & $42,9 \pm 0,36^{\mathrm{e}}$ & $8 \pm 1,73^{b}$ & $9,3 \pm 0,30^{\mathbf{c}}$ & $29,7 \pm 2,00^{\mathbf{e}}$ & $10,1 \pm 0,85^{\mathbf{b}}$ \\
\hline Cocody & $6,7 \pm 1,21^{\mathrm{a}}$ & $6,7 \pm 0,61^{b}$ & $3,3 \pm 0,61^{b}$ & $60 \pm 2,65^{\mathrm{g}}$ & $23,3 \pm 3,56^{\mathrm{d}}$ \\
\hline Koumassi & $30 \pm 2,00^{\mathbf{c}}$ & $3,3 \pm 1,13^{\mathrm{a}}$ & $3,3 \pm 0,52^{b}$ & $46,7 \pm 0,61^{\mathrm{f}}$ & $17,7 \pm 0,52^{\mathrm{c}}$ \\
\hline Marcory & $50 \pm 1,73^{\mathrm{f}}$ & $10 \pm 2,00^{\mathbf{c}}$ & $3,3 \pm 0,13^{b}$ & $26,7 \pm 0,36^{\mathrm{d}}$ & $10 \pm 3,20^{b}$ \\
\hline Port-Bouët & $76,7 \pm 0,70^{i}$ & $3,3 \pm 0,51^{\mathrm{a}}$ & $3,3 \pm 0,52^{b}$ & $10 \pm 1,00^{\mathbf{a}}$ & $6,7 \pm 1,54^{\mathrm{ab}}$ \\
\hline Treichville & $68 \pm 1,00^{h}$ & $17,4 \pm 0,53^{\mathrm{e}}$ & $1,3 \pm 0,30^{\mathrm{a}}$ & $10,3 \pm 0,52^{\mathrm{a}}$ & $3 \pm 1,42^{\mathrm{a}}$ \\
\hline Yopougon & $60 \pm 3,46^{\mathrm{g}}$ & $6,7 \pm 0,52^{b}$ & $3,3 \pm 0,52^{b}$ & $20 \pm 1,32^{\mathbf{c}}$ & $10 \pm 4,90^{b}$ \\
\hline Averages & $43,81 \pm 21,54$ & $9,5 \pm 5,18$ & $4,42 \pm 2,97$ & $27,48 \pm 16,00$ & $14,89 \pm 9,35$ \\
\hline
\end{tabular}

On the same column, the values carrying the same letters do not present a significant difference at the threshold in $5 \%$ according to Duncan's test

Table 3: Distribution of the mode of protection of the groundnut paste during the sale in the marckets

\begin{tabular}{|c|c|c|}
\hline \multirow[t]{2}{*}{ Communes investigated } & \multicolumn{2}{|c|}{ Mode of protection of the groundnut paste during the sale $(\%)$} \\
\hline & Covered groundnut paste & Non covered groundnut paste \\
\hline Abobo & $7,3 \pm 2,04^{\mathrm{a}}$ & $92,7 \pm 2,04^{\mathrm{c}}$ \\
\hline Adjamé & $14,8 \pm 1,06^{b}$ & $85,2 \pm 1,06^{b}$ \\
\hline Attécoubé & $11,5 \pm 3,97^{\mathbf{a b}}$ & $88,5 \pm 3,97^{\mathbf{b c}}$ \\
\hline Cocody & $25,1 \pm 2,15^{\mathbf{c}}$ & $74,9 \pm 2,15^{\mathrm{a}}$ \\
\hline Koumassi & $16 \pm 4,00^{\mathbf{b}}$ & $84 \pm 4,00^{b}$ \\
\hline Marcory & $23,3 \pm 2,86^{\mathrm{c}}$ & $76,7 \pm 2,86^{\mathrm{a}}$ \\
\hline Port-Bouët & $25 \pm 54,58^{\mathrm{c}}$ & $75 \pm 4,51^{\mathrm{a}}$ \\
\hline Treichville & $22,6 \pm 3,83^{\mathrm{c}}$ & $77,4 \pm 3,83^{\mathrm{a}}$ \\
\hline Yopougon & $14,7 \pm 2,46^{\mathbf{b}}$ & $85,3 \pm 2,46^{\mathbf{b}}$ \\
\hline Averages & $17,81 \pm 6,72$ & $82,19 \pm 6,80$ \\
\hline
\end{tabular}

On the same column, the values carrying the same letters do not present a significant difference at the threshold in $5 \%$ according to Duncan's test

\section{Discussion}

The majority of the mills of the principal markets of the surveyed communes were not intended only for the grinding of groundnut seeds. The use of the same mills being used for grinding of groundnut seeds for grinding of other foodstuffs represents a true risk of contamination especially cross contamination of the produced groundnut paste. This observation confirms that of [1]-[15] which after having worked on fermented fish, indicated that the environmental conditions under which the food is produced in Africa are generally nonhygienic; what constitutes a factor of potential risk of microbial contamination of food.

The majority of the mills was not cleaned in the majority of the visited units of grindings. Indeed, according to millers', nonthe cleaning of the mills after use would be due to a lack of time. What reveals a lack of hygiene which can affect the medical quality of the produced groundnut paste. These results corroborate those of [19] which reported in similar studies that the millers did not clean the mills after the preceding productions of groundnut pastes. According to these authors, this practice would predispose the groundnut pastes produced on levels of contamination in moulds.

The investigation also revealed a low educational level of the saleswomen of groundnut paste. That could be due to the fact that the sale of the groundnut paste is an activity which does not require particular competences. What could justify partly, the strong representativeness of the saleswomen not provided education for in this abstract branch of industry. This result is in conformity with that [10] on the transformation and the marketing of the foodstuffs mainly dominated by the women on a low educational level. This study as showed as the sale of the groundnut paste in the markets of Abidjan regresses with the age of the saleswomen gradually in time. One of the principal reasons of the fall of this activity is due to the fact that these saleswomen are made replace by people who are close for them with which they learns the trade from trade for the succession in time. Similar observations were also made by [2] which indicated that in urban environment, majority of the transformer women and saleswomen of foodstuffs profit from the support of the members of their family who replace them later for their idle periods.

The sale of the same stock of groundnut paste in the markets extends over periods from 1 to 3 months. The long periods of sale of the same stock of groundnut paste up to 3 months could be explained for economic reasons. Indeed, with an aim of covering all the funded capital or of carrying out benefit, the saleswomen market the totality of the groundnut paste available, whatever the duration. This long duration of sale of the groundnut paste could be one of the critical periods of its contamination. Indeed, according to [14], the risk of contamination of the groundnut paste increases with its long duration of marketing because of bad practices and many handling.

This study showed that the majority of the saleswomen do not protect the pastes from groundnut during the sale. Indeed, according to these last, the exposure of the groundnut pastes during the retail sale to the free air makes 


\section{International Journal of Science and Research (IJSR) \\ ISSN (Online): 2319-7064 \\ Index Copernicus Value (2013): 6.14 | Impact Factor (2015): 6.391}

it possible to the customers to see them by far. From where, the groundnut pastes are permanently exposed to the free air during marketing. However, according to [15], the immediate environments of the places of sale in the markets of Abidjan are true sources of contamination of any kind in particular the flies (potentials pathogenic tanks of micro-organisms), the water points on the cemented ground, the sewers, the gutters in the open air, the public toilets and the garbage dumps.

\section{Conclusion}

At the end of this study, we can retain that the principal factors of medical risks related to the production of the groundnut paste in the markets are the general-purpose use of the mills, the diversity of the foodstuffs to crush, the frequency of high daily use of the mills and their noncleaning after use. Also, the long durations of sale of the same stock of groundnut paste to the detail, the artisanal production of the groundnut pastes in the other town of the Côte d'Ivoire and their routing towards Abidjan as well as nonthe protection of the groundnut paste during sale were indexed like the factors of medical risks related to the sale of the groundnut pastes in the markets of the town of Abidjan. In a general way, the millers exerting this trade in the markets are unaware of the risks of contaminations especially cross contaminations of various crop products. The bad practices of hygienes noted during the production and the sale of the groundnut paste are factors which could have a negative impact on the hygienic quality of the sold groundnut pastes and the health of the consumers.

\section{References}

[1] B.V. Anihouvi, G.S. Ayernor, J.D. Hounhouiggan et E. Sakyi-Dawson, Caractéristiques de la qualité de lanhouin : un produit de poisson traditionnellement traité et fermenté en république du Bénin, African journal of Food, 6 (1), pp. 1-15, 2006

[2] C. Broutin et J. Rouyat, Education qualifiante des jeunes et adultes (EQJA). Etude sur les formations des femmes dans le domaine de l'agroalimentaire. Gret-Sénégal, p. 92, 2004.

[3] P.M. Diedhiou, R. Bandyopadhyay, J. Atehnkeng et P.S. Ojiambo, Aspergillus colonization and aflatoxin contamination of maize and sesame kernels in two agroecological zones in Senegal, Journal of Phytopathology, 159, pp. 268-275, 2011.

[4] DSDI/MINAGRI, Direction des Statistiques, de la Documentation et de l'Informatique/Ministère de l'Agriculture (Côte d'Ivoire), Annuaire des Statistiques Agricoles 2010-2012, Edition 2010-2012, p. 63, 2012.

[5] J. Eke-Ejiofor, D.B. Kiin-Kabari et E.C. Chukwu, Effect of processing method on the proximate, mineral and fungi properties of groundnut (Arachis hypogea), Seed Journal of Agricultural and Biological Science, 3, pp. 257-261, 2012.

[6] J. Eke-Ejiofor, D.B. Kiin-Kabari et C.E. Chukwu, Effect of processing method on the proximate, mineral and fungi properties of groundnut (Arachis hypogea). Seed Journal of Agricultural and Biological Science, 3, pp. 257-261, 2012.
[7] FAOSTAT, Statistical databases. Available online at : http://www.fao.org. Accessed at December 26, 2014. (General Internet site)

[8] FAOSTAT, Production data. Available online at : http://faostat.fao.org. Accessed at September 15, 2008. (General Internet site)

[9] M.E. Ferguson, A. Jarvis, H.T. Stalker, D.E. Williams, L. Guarino, J.F. Valls, R.N. Pittman et P.J. Bramel, Biogeography of wild Arachis (Leguminosae): distribution and environmental characterisation. Biodiversity and Conservation, 14, pp. 1777-1798, 2005.

[10] G.E. Fraser, Nut consumption, lipids, and risk of a coronary event, Asia Pacific Journal of Clinical Nutrition, 9, pp. 28-32, 2000.

[11] Grain de sel, Valorisation des produits tropicaux : face aux défis, une diversité de solutions. Revue interréseaux, 58, pp. 1-48, 2012.

[12] A.E. Griel, B. Eissenstat, V. Juturu, G. Hsieh et P.M. Kris-Etherton, Improved diet quality with peanut consumption, Journal of the American College of Nutrition, 23, pp. 660-668, 2004.

[13] A. Jarvis, M.E. Ferguson, D.E. Williams, L. Guarino, P.G. Jones, H.T. Stalker, J.F.M. Valls, R.N. Pittman, C.E. Simpson et P. Bramel, Biogeography of Wild Arachis. Assessing Conservation Status and Setting Future Priorities. Crop Science, 43, pp. 1100-1108, 2003.

[14] C. Kapseu, Production, analyse et applications des huiles végétales en Afrique, Oilseeds fats Crops and Lipids, 16 (4), pp. 215-229, 2009.

[15] A.N. Kaaya, C. Harris et W. Eigel, Peanut aflatoxin levels on farms and in markets of Uganda. Peanut Science, 33, pp. 68-75, 2006

[16] R. Koffi-Nevry, A.S. Wognin et K.S. Ouffoué, Assessment of health risk factors associated with conditions of lettuce (Lactuca sativa) sale in Abidjan (Côte d'Ivoire) markets, Food Global Science Books, 6 (1), pp. 71-75, 2012.

[17] J.L. Knoden, L. Dufour et J. Bindelle, Fabrication de beurre de cacahuète, Collection Manuels et Techniques, Belgique, p. 14, 2003.

[18] M.A. Montfort, Filières oléagineuses africaines, Notes et Études Économiques, 23, pp. 55-85, 2005.

[19] C. Mutegi, J. Kimani, G. Otieno, R. Wanyama, M.E. Christie, K. Mallikarjunan et A. Kaaya, Peanut aflatoxin levels under different market attributes, East African Agricultural and Forestry Journal, 77, pp. 95-103, 2010.

[20] J.W. Ndung'u, A.O. Makokha, C.A. Onyango, C.K. Mutegi, J.M. Wagacha, M.E. Christie et A.K. Wanjoya, Prevalence and potential for aflatoxin contamination in groundnuts and peanut butter from farmers and traders in Nairobi and Nyanza provinces of Kenya, Journal of Applied Biosciences, 65, pp. 4922-4934, 2013.

[21] K. Noba, A. Ngom, M. Guèye, C. Bassène, M. Kane, L. Diop, F. Ndoye, M.S. Mbaye, A. Kane et A.T. Ba, L'arachide au Sénégal : état des lieux, contraints et perspectives pour la relance de la filière, Oilseeds Crpos and Lipids Journal Organisation, 21 (2), pp. 1-5, 2014.

[22] C.I. Revoredo et S. Fletcher, World peanut market: an overview of the past 30 years, Georgia Agricultural Experiment Stations, College of Agricultural and Environmental Sciences, the University of Georgia, $p$. 22, 2002.

[23] N. Sanginga et D. Bergvinson, Un plan d'action pour la transformation de l'agriculture africaine. Oléagineux et Niébé, pp 27, 2015 